serum calcium and a drop in the serum phosphate. Unfortunately it was not stated whether there was radiological evidence of secondary hyperparathyroidism.

The feature that emerges from the present study is that augmented phosphaturia is by no means a constant finding in osteomalacia. Thus this measurement is not a useful clinical test for the presence of osteomalacia. It is, however, of conceptual interest to find that this is so, as it points to failure of an increase in parathyroid hormone secretion as a likely cause of the well-documented occurrence of osteomalacia without overt evidence of secondary hyperparathyroidism. The cause of such failure is not shown from the present study. Possibly this failure is relatively common in that a proportion of patients with renal failure also fail to manifest secondary hyperparathyroidism (Stanbury and Lumb, 1966), though the mechanisms involved might be different. Direct assay of serum parathyroid hormone is required to pursue this question further. In addition, it is confirmed from our series that the 24-hour strontium space is a sensitive practical test for screening for osteomalacia in that it was the only measurement that was found to be abnormal in every patient.

We are grateful to the department of chemical pathology for some of the serum estimations, to the department of morbid anatomy for their reports on the bone biopsies, to the staff of the metabolic unit, and to Miss Rita Hessey for assistance with the statistical calculations. Sandoz Ltd. (Dr. D. S. Freestone) generously supplied the strontium. We would also like to express our thanks to Professor Russell Fraser for his helpful criticism of the manuscript. N.C.T. gratefully acknowledges a W.H.O. Fellowship.

REFERENCES

Albright, F., and Reifenstein, E. C. (1948). The Parathyroid Glands and Metabolic Bone Disease, p. 216. Baltimore, Williams \& Wilkins.
Arnaud, C. D., jun., Tenenhouse, A. M., and Rasmussen, H. (1967). Annual Review of Physiology, 29, 349.

Arnstein, A. R., Frame, B., and Frost, H. M. (1967). Annals of Internal Medicine, 67, 1296.

Au, W. Y. W., and Raisz, L. G. (1965). American fournal of Physiology, 209, 637.

Bartos, H. R., and Henneman, P. H. (1965). Fournal of Clinical Endocrinology and Metabolism, 25, 1522 .

Beutner, E. H., and Munson, L. P. (1960). Endocrinology, 66, 610

Bordier, P., et al. (1968). Lancet, 1, 437.

DeLuca, H. F. (1967). Vitamins and Hormones, 25, 315

de Wardener, H. E. (1967). The Kidney, 3rd ed., p. 75 . London, Churchill. step, H., et al. (1969). Journal of Clinical Endocrinology and Metabolism, 29,842 .

Evanson, J. M. (1966). Clinical Science, 31, 63.

Fourman, P., and Haapanen, E. (1964). Schweizerische medizinische Wochenschrift, 94, 886.

Fourman, P., and Royer, P. (1968). Calcium Metabolism and the Bone, 2nd. ed., p. 285. Oxford, Blackwell.

Fraser, D., Kooh, S. W., and Scriver, C. R. (1967). Pediatric Research, 1, 425

Gershberg, H., Shields, D. R., and Kove, S. A. (1959). Fournal of Clinical Endocrinology and Metabolism, 19, 681 .

Goldman, R., and Bassett, S. H. (1954). Fournal of Clinical Investigation, 33, 1623 .

Hiatt, H. H., and Thompson, D. D. (1957). Fournal of Clinical Investigation, 36, 557.

Joplin, G. F., Robinson, C. J., Melvin, K. E. W., Thompson, G. R., and Fraser, R. (1967). In l'Osteomalacie, edited by D. J. Hioco, p. 249. Paris, Masson.

Joplin, G. F., Melvin, K. E. W., Hepner, G. W., Neale, G., and Bordier, P. (1968). Calcified Tissue Research, 2, Suppl., 63.

Mickerson, J. N. (1960). British Medical fournal, 1, 529.

Milne, M. D., Stanbury, S. W., and Thomson, A. E. (1952). Quarterly fournal of Medicine, 21, 61 .

Nordin, B. E. C. (1961). Proceedings of the Royal Society of Medicine, 54, 497. Nordin, B. E. C., and Fraser, R. (1960). Lancet, 1, 947.

Rasmussen, H., DeLuca, H., Arnaud, C., Hawker, C., and Von Stedingk, M. (1963). Yournal of Clinical Investigation, 42, 1940.

Salvesen, H. A., and Böe, J. (1953). Acta Medica Scandinavica, 146, 290 Singer, F. R., Woodhouse, N. J. Y., Parkinson, D. K., and Joplin, G. F (1969). Clinical Science, 37, i81.

Stanbury, S. W., and Lumb, G. A. (1966). Quarterly fournal of Medicine, $35,1$.

Taitz, L. S., and de Lacy, C. D. (1962). Pediatrics, 30, 884.

Wootton, I. D. P. (1964). Micro-analysis in Medical Biochemistry, 4th ed. London, Churchill.

\title{
Alterations in Lumbar Cerebrospinal Fluid Protein During Air Encephalography
}

\author{
J. RANALD W. DYKES, ${ }^{*}$ M.B., CH.B., B.SC. ; DAVID L. STEVENS, $†$ M.B., M.R.C.P.
}

Cummary: A significant fall occurred in the protein content of successive specimens of lumbar cerebrospinal fluid (C.S.F.) withdrawn during the course of air encephalography in $57 \%$ of cases. No correlation was found between the fall in the protein concentration and the total volume of air injected or the total volume of C.S.F. withdrawn, but the size of the fall was greater when the initial lumbar C.S.F. protein concentration was raised. The importance of taking specimens for routine laboratory analysis before the injection of any air is emphasized.

\section{Introduction}

In the investigation of neurological disease, protein concentration is often determined in cerebrospinal fluid (C.S.F.) removed at lumbar puncture and then later in a specimen withdrawn during air encephalography. Under these circumstances it is often noted that the concentrations are different and occasionally widely so. This discrepancy can be particularly confusing if one of the two readings is within the normal range and the other is outside it. The present investigation has been carried out in an attempt to clarify this situation.

* Lecturer in Chemical Pathology, School of Medicine, Leeds.

+ Senior Registrar in Neurology, the General Infirmary at Leeds.
Since Dandy (1919) introduced the technique of air encephalography there have been many reports on the changes in the cellular content of the C.S.F. during and after the procedure (Aird, 1936; Lund and Neel, 1941; Frick, 1956; Roskamp, 1961), but few reports have dealt with the changes in the protein concentration, although it has been known for many years that the protein content of the ventricular C.S.F. is lower than that in the cisterna magna and the lumbar theca (Lups and Haan, 1954). Schwab and von Storch (1937) investigated the protein concentration of lumbar C.S.F. withdrawn at 15-minute intervals during the hour taken to perform air encephalography in 59 patients. They found a decrease in the protein content during the replacement of C.S.F. by air, followed by a return to the original value by the end of the procedure. Bickerstaff $(1950,1951)$ determined the protein concentration in the initial and final lumbar C.S.F. specimens in 57 patients and found a fall in 24 , no change in 23 , and a rise in the remaining 10. Marrack et al. (1961) measured the protein content before and after air encephalography in 81 patients. In 78 they noted a drop, which averaged $11 \mathrm{mg} . / 100$ $\mathrm{ml}$.

In this paper the drop in protein content has been examined with particular reference to the volume of air injected, the volume of C.S.F. withdrawn, and the initial lumbar fluid protein concentration. Because of previous comprehensive 
study by many workers (Aird, 1936; Lund and Neel, 1941; Frick, 1956; Roskamp, 1961) the cells have not been looked at, but in a few of our cases we have performed Lange colloidal gold curves on serial specimens and assayed the glucose and chloride concentrations.

\section{Patients and Methods}

Thirty patients were studied, 15 males and 15 females. Twenty-six of them were adults aged 17 to 67 years (average $46 \pm 15$ ); the remaining four were children aged 4 to 12 years. The diagnoses were as follows: (a) eight of temporal lobe epilepsy, (b) eight of other types of epilepsy, $(c)$ three of either cerebral or cerebellar atrophy, $(d)$ two of Parkinsonism, (e) two of developmental speech disorders, and one each of suprasellar tumour, astrocytoma of the corpus callosum, polioencephalitis, "punch-drunk" syndrome, multiple cranial nerve palsies (? demyelinating disease), bilateral exophthalmos of uncertain aetiology, and subdural haematoma.

The 30 cases were selected from a large number in whom air encephalography had been performed; the remainder were rejected either because less than $1 \mathrm{ml}$. of C.S.F. had been obtained in one of the specimens or because some air had been inserted before the withdrawal of the first specimen. A minimum of four serial specimens was obtained from all except two of the cases studied.

The air encephalography procedure, lasting about $40 \mathrm{~min}-$ utes, was performed under neuroleptoanalgesia in the 26 adult cases, and under general anaesthesia in the four children. With the patient in a sitting position, lumbar puncture was carried out at either the $\mathrm{L} 3 / 4$ or $\mathrm{L} 4 / 5$ interspace. A specimen of C.S.F. was withdrawn before beginning and following each injection of air. On each occasion the volume of the air and the C.S.F. was measured. Air was injected two to six times, totalling $21-55 \mathrm{ml}$, until the $x$-ray picture was satisfactory. Accordingly there were three to seven C.S.F. specimens, totalling $13-52 \mathrm{ml}$. in volume. The withdrawal of C.S.F. after each air injection was the only departure from the radiologist's normal procedure.

All specimens from 24 of the cases were analysed in duplicate. Each sample was coded and passed to the laboratory in an order from which it could not be identified by the technical staff. In the remaining six cases each specimen was analysed once.

The protein concentration was assayed by the turbidimetric method of King and Haslewood (1936), 3\% sulphosalicylic acid and the Unican SP300 with a red filter being used. Hyland Laboratories Clinical Chemistry Control Serum diluted to about $70-75 \mathrm{mg} . / 100 \mathrm{ml}$. was used as standard. The within-batch analytical error-that is, two standard deviations of $2.6 \mathrm{mg} . / 100$. ml.-was determined from duplicate assays on 60 specimens ranging in concentration from 10 to 79 mg./100 ml., by the formula $s=\sqrt{\frac{\Sigma D^{2}}{N}-(\bar{D})^{2}}$

where $\mathrm{D}$ is the difference between the duplicate assays on any one specimen, $\overline{\mathrm{D}}$ is the mean of all the differences between the duplicates, and $\mathrm{N}$ is the number of duplicates. In our laboratory $20-40 \mathrm{mg} . / 100 \mathrm{ml}$. is used as a working normal range.

Glucose was estimated by the glucose oxidase method (Marks, 1959) (the within-batch analytical error $\pm 8 \mathrm{mg}$./ $100 \mathrm{ml}$.). Chloride was assayed by the method of Schales and Schales (1941); the normal range is $120-130 \mathrm{mEq} /$ litre and the within batch analytical error $\pm 3 \mathrm{mEq} /$ litre. The Lange colloidal gold test was performed by the method of Maclagan (1946), sodium chloride being used as diluent.

The techniques of analysis of variance and linear regression were used in the statistical treatment of the data (Moroney, 1962). Student's $t$ test was applied to assess whether the slopes of the regression lines were significantly different from zero.

\section{Results}

The general trend was towards lower values in C.S.F. protein concentration at the end of the procedure, but individual cases varied considerably, as is illustrated in the chart.

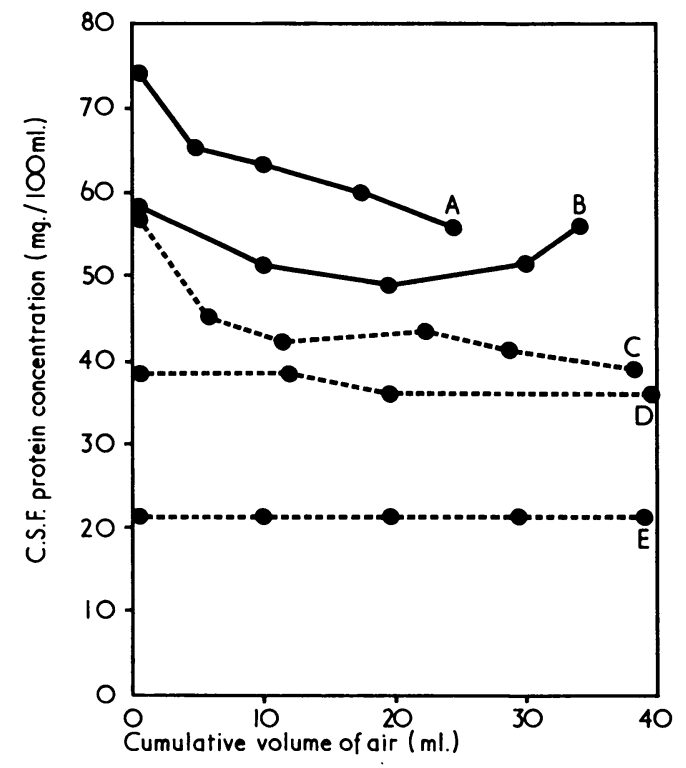

Plot of C.S.F. protein concentration against cumulative volume of air during air encephalography for five individual cases.

Regression line slopes of the protein concentration in each specimen against (1) the cumulative volume of air injected and (2) the cumulative volume of C.S.F. withdrawn were calculated for all 30 cases. Twenty-eight of the 30 slopes in each category were negative. Student's $t$ test showed that 17 of the 30 slopes $(57 \%)$ in group 1 and $15(50 \%)$ in group 2 were significantly different from zero $(\mathrm{P}=0.05$ or less). Our average protein drop of $8.1 \mathrm{mg} . / 100 \mathrm{ml}$. was slightly less than that of $11 \mathrm{mg} . / 100 \mathrm{ml}$. recorded by Marrack et al. (1961) in their 78 cases. The only factor common to the cases with regression line slopes not significantly different from zero was an initial protein concentration $<40 \mathrm{mg}$. $/ 100 \mathrm{ml}$.

In 18 of the 30 patients a total volume of at least $35 \mathrm{ml}$. of air was injected. An analysis of variance carried out on the differences between the initial lumbar protein concentration and the concentration after the injection of $35 \mathrm{ml}$. of air in these 18 patients showed that in those cases with an initial protein value $>40 \mathrm{mg} . / 100 \mathrm{ml}$. there was a significantly greater drop $(P=0.01)$ than in those with an initial protein value $<40 \mathrm{mg} . / 100 \mathrm{ml}$. The range of drop in the former group of cases was $6.5-20.5 \mathrm{mg} . / 100 \mathrm{ml}$. (average 11.8) compared with $0-12 \mathrm{mg} . / 100 \mathrm{ml}$. (average 4.4 ) in the latter group. In six patients, five of whom had an initial protein concentration $<40 \mathrm{mg} . / 100 \mathrm{ml}$., thtere was a greater drop between the first and second specimens than between subsequent ones.

In four patients the initial lumbar C.S.F. specimen had a moderately raised protein concentration, whereas the final specimen gave a value within or at the upper limit of the working normal range for our laboratory (see Chart, line C).

No particular pattern of change in the C.S.F. protein concentration was found to correlate either with the mode of distribution of the air within the skull or with the clinical diagnosis in each case.

In two of our patients, after a fall in protein concentration, we observed a subsequent rise to a final value closely similar to or even exceeding that of the initial specimen (see Chart, line B). Marrack et al. (1961) observed this in 3 out of 81 cases, whereas Schwab and von Storch (1937), Lund and Neel (1941), and Bickerstaff $(1950,1951)$, all of whom used much larger volumes of air than ourselves and Marrack et al., de- 
scribed it much more frequently. Presumably the larger the volume of air injected the more rapidly will the arachnoid membrane permeability be altered by the irritant effect of the air (Aird, 1936; Bohn, 1937; Roskamp, 1961) and hence the more quickly will the lumbar C.S.F. protein level rise. The modern trend towards using much smaller volumes of air suggests that this phenomenon will be observed much less frequently.

In seven cases glucose and chloride estimations were performed on all of the specimens, but no pattern of significant rise or fall emerged. Similarly no significant pattern of change could be detected in the Lange colloidal gold curves carried out on all of the specimens from six cases. These findings are in agreement with those of Schwab and von Storch (1937), Bickerstaff (1950), and Marrack et al. (1961).

\section{Discussion}

Though various authors have given different values for the normal range of C.S.F. protein at different sites throughout the central nervous system, all agree that the concentration is lowest in the ventricles and highest in the lumbar theca (Lups and Haan, 1954; Hill et al., 1958; Hunter and Smith, 1960). Schwab and von Storch (1937) and Bickerstaff (1951) attributed the mechanism of the fall during air encephalography to dilution of the lumbar C.S.F. by ventricular and cisternal C.S.F. of lower protein concentration which was displaced downwards by the injected air. We have shown a significantly greater drop ( $P=0.01)$ when the initial lumbar protein concentration was $>40 \mathrm{mg}$. $/ 100 \mathrm{ml}$. This observation is in agreement with (a) the work on forced drainage of C.S.F. done by Fremont-Smith et al. (1930), who demonstrated a larger fall in protein concentration when the initial value was raised, and $(b)$ the finding by Lups and Haan (1954) that in patients with disease of the central nervous system without a spinal block there existed a larger difference between the lumbar and ventricular C.S.F. protein concentrations than occurred in the normal state.

On account of this downward displacement during air encephalography we emphasize that C.S.F. specimens for protein analysis should always be taken before the insertion of any air. If, as often happens, the specimen is taken after the initial injection then falsely low values for protein may be found, since, as six of our cases showed, there was a greater drop between the first and second specimens than between subsequent ones, particularly if the initial protein concentration was $>40 \mathrm{mg} . / 100 \mathrm{ml}$. Similarly, in view of the greater magnitude of the gradient when the initial protein concen- tration is $>40 \mathrm{mg} . / 100 \mathrm{ml}$., a raised value might be missed if the laboratory specimen is withdrawn after air encephalography is finished. Four of our cases illustrated this point (see Chart, line C).

In relation to a particular patient the clinician may desire to know the significance of an apparent change in a biochemical result-for example, the neurologist may wish to compare two C.S.F. protein values from the same patient, both of which are subject to analytical error. If the formula of Campbell and Owen (1967) is applied to our C.S.F. protein results there is a $95 \%$ chance of the difference being significant if the two C.S.F. protein values differ by more than 2.75 times the standard deviation-that is, applying our own figure, $2.75 \times 1.3=3.6 \mathrm{mg} . / 100 \mathrm{ml}$. This applies only if the two C.S.F. specimens are analysed in the same batch; if they are estimated in separate batches then the difference will be larger because of the larger standard deviation.

We wish to thank Professor G. H. Lathe for advice and encouragement; Dr. M. J. Parsonage for advice and for permission to study the patients under his care; the various radiologists in the department of diagnostic radiology at the Leeds General Infirmary who obtained the specimens of C.S.F. for us; the technical staff of the department of chemical pathology who performed the assays; Mr. J. A. Lewis, of the department of statistics at Leeds University, for advice concerning the statistical analysis of the data and Miss Mary Brown and Mr. R. Cartwright for assistance with preparation of the Chart.

\section{REFERENCES}

Aird, R. B. (1936). Archives of Surgery, 32, 193.

Bickerstaff, E. R. (1950). Lancet, 2, 683.

Bickerstaff, E. R. (1950). Lancet, 2, 683.

Bohn, S. S. (1937). Bulletin of the Neurological Institute of New York, 6, 540 Campbell, D. G., and Owen, J. A. (1967). Clinical Biochemistry, 1, 3.

Dandy, W. E. (1919). Annals of Surgery, 70, 397

Fremont-Smith, F., Putnam, T. J., and Cobb, S. (1930). Archives of Neurology and Psychiatry, 23, 210.

Frick, E. (1956). Deutsche medizinische Wochenschrift, 81, 1168.

Hill, N. C., McKenzie, B. F., McGuckin, W. F., Goldstein, N. P., and Svien, H. J. (1958). Proceedings of the Staff Meetings of the Mayo Clinic, 33, 686 .

Hunter, G., and Smith, H. V. (1960). Nature, 186, 161.

King, E. J., and Haslewood, G. A. D. (1936). Lancet, 2,1153

Lund, E., and Neel, A. V. (1941). Acta Psychiatrica et Neurologica, 16, 459.

Lups, S., and Haan, A. M. F. H. (1954). The Cerebrospinal Fluid, Amsterdam, Elsevier

Maclagan, N. F. (1946). British Fournal of Experimental Pathology, 27, 369. Marks, V. (1959). Clinica Chimica Acta, 4, 395.

Marrack, D., Marks, V., and Couch, R. S. C. (1961). British fournal of Radiology, 34, 635.

Moroney, M. J. (1962). Facts from Figures, London, Penguin Books.

Roskamp, H. (1961). Archiv für Psychiatrie und Nervenkrankheiten, 201,

Schales, O., and Schales, S. S. (1941). Fournal of Biological Chemistry

Schwab, R. S., and von Storch, T. J. C. (1937). New England Fournal of Medicine, 217, 21. 